\title{
ESOPs, CEO entrenchment and corporate social performance
}

\author{
Anis JARBOUI \\ University of Sfax (ISAAS)-Tunisia
}

Email address:

anisjarboui@yahoo.fr

\section{To cite this article:}

Anis JARBOUI. ESOPs, CEO Entrenchment and Corporate Social Performance. International Journal of Business and Economics Research. Vol. 2, No. 6, 2013, pp. 116-129. doi: 10.11648/j.ijber.20130206.11

\begin{abstract}
The purpose of this study is to examine whether employee stock ownership plans (ESOPs) and CEO entrenchment affect social performance. Our central question: does employees' participation in the system of corporate governance (shareholding and presence in the boards of directors and supervisory boards) influence social performance in the context of manager's active behavior? One important result of the multi-varied analyses (logistic regression) is that on the whole employees, if they exert an influence on the determination of social performance in the context of non-financial French firms, are relatively powerless, on their own to explain this complex phenomenon. The findings contribute to explain the social performance and they have implications for firms that decide to engage in ESOP plans in French context.
\end{abstract}

Keywords: Employee Stock Ownership Plans, Board of Directors, CEO Entrenchment, Social Performance, France

\section{Introduction}

Employee shareholding is a phenomenon which has developed in most industrialized and emerging countries. The development of employee shareholding has led to a significant interest in this phenomenon among academia as well as among practitioners. In fact, employee shareholding is at the heart of reflections on corporate governance, as it constitutes one of the ways of accompanying its changes which are underway ([14], [64], [71], [56], [5], [33], [69], [46], [77] and [60].

Even though on a theoretical level, in the context of a partnership governance, the positioning of employee shareholding is fully justified and on an empirical level, it is in a phase of progressive development, nonetheless this topic is the subject of a set of empirical studies that seems insufficiently expanded in France except for, as far as we are concerned, the research of [82], [29], [83], [28], [69], [46], and [39]. These French studies, generally aiming at emphasizing the benefits of employee shareholding, have often sought to demonstrate their positive impact on value creation. Falling within this perspective, our research aims at showing the impacts of employee shareholding on investment in human capital, which are rarely taken into account in the existing research.

In France, according to, [8], [28], [5] and [32]employee participation in firms governance is not limited to taking the participation of the latter in the capital of their firm, but it also results from their active presence in the boards of directors and supervisory boards. Indeed, the development of employee shareholding in France has gradually made a number of firms to take interest in the role of employee directors within their boards of directors. While, According to facts/Obviously, employees participation in the system of corporate governance is growing, while being strongly encouraged and defended in France, no empirical study has, to our best knowledge, and in the French context, linked the degree of employee participation in the capital and the Board of Directors to social performance.

Gordon and Pound (1990) [45], [63] and [38] have postulated that employee shareholding can allow managers to entrench themselves and to better master governance mechanisms. In fact, employee shareholding creates a dependency of employee shareholders vis-à-vis the manager. The latter is at the same time their employer and their representative on behalf of the funds they have invested in their firm [41]. According to [38], employee shareholders find difficulties to break free from their dependence vis-à-vis their managers and to avoid their influence. In the French context, [42] observed that the more employee shareholding is important (more than 5\%), the more managers are able to entrench themselves. Thus, it seems necessary to include the impact of the manager's 
entrenchment policy and managerial discretion on social performance.

Based on these findings, our research focuses on a central question: to what extent does employees' participation in the system of corporate governance (shareholding and presence in the boards of directors and supervisory boards) influence social performance in the context of manager's active behavior?

In an attempt to answer this research question, the current article is divided into four parts. The first two parts restore key elements of a literature analysis which allows us to study the social performance through the theories of corporate governance. In the second part, we have specially focused on research hypotheses. The third part discusses details the features of the empirical study that we conducted the used sample as well as the methodological choices. The last part introduces the obtained results as well as their interpretation and the respective discussion.

\section{Conceptual Framework}

The role of employee shareholding is studied in two opposing research trends. The agency theory substantiates the idea of an employee shareholder who controls the managerial discretion. The entrenchment theory substantiates the thesis that employee shareholding is a lever for the manager's entrenchment and a source for the increase of his managerial discretion.

\subsection{Employee Participation in Governance Bodies}

Based on the works of [22] and [47], the theory of partnership agency showed that the relationship between shareholders (providers of financial capital) and employees (providers of human capital) may be conflictual insofar as the two parties do not always have the same objectives in terms of resource allocation. The value of the specific assets of the employee, his "know-how", depend on the company's situation and especially on the risk related to its demise. This situation may cost him expenses from the moment that the company undertakes specific investments. The fact of favoring the interests of shareholders can lead the control coalition to take decisions contrary to the interests of other organization partners in particular employee decisions. According to several studies, company downsizing, accompanied by a market rise, aims to satisfy shareholders [40]. Similarly, according to the agency theory, employees may endorse harmful conduct to shareholders interests, in particular through increasing the level of their absenteeism and reducing their work intensity, which can lead to a profitability reduction and value destruction.

According to [36], the employee is in the situation of an individual who has accumulated experience and qualifications and who leases an asset (a specific job) to the firm. The value of this asset can diminish, or even be cancelled, if the employee loses benefits related to his job, if he is dismissed due to a sub-optimal behavior of the company or if the latter fails. As a result, the fear of being dismissed may encourage employees to propose investments in order to preserve their jobs [11], [13] and [54]. The existence of a situation of conflicting interests requires the establishment of mechanisms to preserve employees' interests. According to [59], it is currently interesting to notice a common desire to reconcile the interests of shareholders and employees. This is reflected in firms by the constant efforts meant to favor all shareholders (including employees) and to moderate the benefit granted at the sole creation of shareholder value. Williamson (1985), [28] and [77] have thus pointed out that employee representation in the board of directors would allow a better information sharing and a more effective cooperation between the various types of shareholders. Koike (1990) [90] stated that it is the risk assumed by the employees which gives them legitimacy to control the decisions which affect their career as well as their heritage. The nature of employee participation in the governance of their firm may oppose, in a certain way, the force of the pressure exerted by financial stakeholders. The compensations may be significant and are in particular reflected by a strengthening of the security level of jobs that the firm may grant to its employees [6]. According to [72], the more employees have high human capital, the more they can control access to key resources of the firm, not only develop them but also appropriate them to increase their human capital. According to the last two authors, the partnership approach of governance has led to a different view of shareholding structure and of the composition of the board of firms. It has allowed the various firms partners, including employees, to have property rights and to participate in the Board of Directors. Blair (1999) [99] argues that human capital has become as fluid as financial capital. Workers' human capital requires a special follow-up within firms and gives certain legitimacy to employees to participate in corporate governance like the other shareholders [65].

\subsection{Entrenchment and Manager's Active Behavior}

The theory of corporate governance grants an active role for firms' managers, which is particularly useful in the context of the analysis of their strategies of defense and of governance mechanisms neutralization. However, the theory of corporate governance, which includes the entrenchment theory, highlights the fact that the leader can counter this disciplinary means [51]. In fact, the leader is able to follow an active strategy, enabling him to expand his discretionary space through neutralizing certain constraints bearing on his management. In this context, many studies have pointed to the existence of deviation strategies adopted by managers in order to eschew control mechanisms or to overcome them [47], [62] [7], and [81] explained that the manager who seeks to entrench himself uses the firm's resources in order to invest in specific investment projects, which make its replacement costly for shareholders. Other authors including [62], [27], and [2] postulated that diversification investments can be analyzed 
as means for increasing power, managers' entrenchment and reducing other business partners. Some studies [63], and [28] note that employee shareholding is likely to encourage management's entrenchment. Park and Song, (1995) [63]state that this entrenchment is easy as the degree of independence of employee shareholders with respect to the leader is weak.

\section{Research Hypotheses}

In this part, we will tackle the consequences of employees' participation in the share capital and in the Board of Directors of companies that employ them, as well as the impact of entrenchment strategies of their

\subsection{The Effects of Financial Participation of Employees and their Presence in Governance Bodies}

Employee shareholding contributes to creating a positive employment relationship which on the one hand, leads to the development of perceptions relating to the existence of common interests and shared purposes and on the other hand, develops the willingness to cooperate [52]. According to [32] employees are encouraged to cooperate rather than to come into conflict in order to participate in the creation and allocation of rents processes.

Thus, financial contribution creates an important modality at the disposition of employees to enable them to become more involved in the mechanisms of businesses decision-making, [50]. This path aims at offsetting the weight of capitalist shareholders, because as underlined by[1]: "employee shareholders are deemed to have a logic that is less short-term than institutional shareholders." In this context, employees become full shareholders, they participate in votes during ordinary and extraordinary general meetings and they can exercise their power in firm management. It is clear from most studies that employee shareholding promotes higher motivation and employee involvement, [58], a reduced absenteeism and turnover, an improved production quality and increased productivity ([77], [54], and [60]. However, according to [57] the beneficial results expected from employee shareholding, in terms of human resources (motivation, effort...) are only achieved through a significant control exercised by the latter.

Employees remuneration through granting shares may also provide a mechanism which can encourage investment in human capital [12], [74], and [60]. In the same vein, [55] and [30] highlighted the existence of a positive relationship between employee incentive modalities and their level of satisfaction in general, as well as the increase of their sense of job security. According [73] with employee shareholding, employees are less likely to be dismissed especially during mass unemployment where none is really secure from losing his job. A recent study carried out by the European Foundation for the Improvement of Living and Working Conditions (Eurofound), and whose purpose is to study the financial participation of employees in some 2,500 European companies having more than 200 employees during the period $1999-2000$, is instructive. Researchers have thus found that the use of this formula contributes to protecting the value of investment in human capital as well as in training and qualification of personal. Pendleton et al. (1998) [65] showed in their study that an increasing in the participation of employees in the capital has a positive impact on the decisions which enhance employees' training and skills. Finally, Robinson and Zhang (2005) [75] have empirically shown that employees shareholding in Great Britain encourages commitment, loyalty and safeguard investments of the human capital of workers. Hence our first hypothesis:

H 1: The Employee share ownership plan (ESOPs) is positively related to social performance.

According to [14] the new powers relating to employees shareholding are thus indirect powers which will be exercised by their representatives. The development of shareholding can lead employees to serve on the board of directors or supervisory board. According to [18] the German model of governance grants a great importance to employees, in such a way that the latter can be found in the supervisory board. This right known as co-determination allows employees to participate in determining their rights relating to work hours, dismissals and training. It is in this context that [28] mentioned that "by allowing them to protect their investment in human capital specific to the firm, the representation of employees in the board leads to an amelioration of employee's satisfaction, involvement and productivity, and promotes the speeding up of process of innovation and a higher quality ..."

In the same vein, the report established by the French Institute of Corporate Governance [49] appointed administrators employees as an asset to the company and all governance actors including employees. According to this report, it is logical to observe a correlation between the intensity of human capital deployed in the business project and the presence of administrators employees.

According to [44] employees' participation in the board of directors has many advantages. First, it ensures a certain level of democracy in the firm through imposing the participation of employees in strategic decisions. Second, it allows to protect the investment in human capital, through ensuring job security to employees, improving business productivity and creating a good social climate. Finally, comanagement allows them to exchange credible information and control managers more effectively.

In the same vein, according to [79] this system enables to reduce the asymmetry of information supported by shareholders, as well as limit managers' opportunistic behavior and discretionary latitude.

Co-management can also improve employees' satisfaction [35]. It is manifested by the development of new ways to allocate staff, by changes in work hours and investment decisions in training and qualification. However, according to [73] representative participation, aligned with 
the existing trade union structures, seems more effective as representatives certainly act very seriously, the trade unions are anxious to protect the value of the investment of employees, and eager to support management commitments to do so. Thus, we deduce our second hypothesis:

H2: The presence of the administrators "employee shareholders "in the board of directors or supervisory boards of firms is positively related to social performance.

\subsection{The Impact of Managerial Entrenchment Strategy}

According to [47], [62], and [85] the fact that managers observe some specific commitments (implicit and explicit) vis-à-vis a stakeholder can help establish a trust relationship as well as a relaxation of the control carried out by all stakeholders. In our case, employees, as company partners, contribute to the development of a significant entrenchment ground, insofar as they can support him in the event of a conflict with certain shareholders or members from the board of directors. Thus, the manager who wishes to expand his discretionary space and to delimit employees' control power has all the interest in promoting investment in human capital. Managers can promise employees an amelioration of job security, faster promotions, more interesting remunerations [24] and [51]. According to [86] the manager tends to invest in businesses with high growth potential in order to maintain his implicit contracts with employees (various investments in human capital). According to the same author, the respect of these contracts strengthens his entrenchment in the firm because employees affected by these agreements tend to remain faithful to him. All these conditions lead employees to grant greater confidence to managers. Moreover, it leads them to relax their control exercise and contribute to the expansion of the manager's discretionary space. Similarly, according to [62] in their anti-takeover battles, managers most often seek to defend their own position. In these situations, they often get employees' support, the main argument being generally defending jobs. In the same vein, [70] and [38] showed that managers may be tempted to establish employee share mechanisms in a defensive purpose in order to protect themselves against takeovers and thus promote their entrenchment.

Privileged relationships, likely to exist with the influential agents in the economy or the State, can also constitute a valuable source of entrenchment. In fact, investments in human capital and especially job creation and putting downsizing policies on standby are very advantageous for managers because these measures allow them to amplify their distinctive relationships with their agents intervening at State level [81]. This good image especially established with politicians can enhance the manager's human capital, increase his value in the labor market and guarantee his external entrenchment strategy. Our third hypothesis is the outcome of these analyses:

H3: The managerial entrenchment is positively related to social performance.

\section{Characteristics of the Study}

This section is denoted to present our sample as well as the operationalization of the applied variables, information sources and estimation techniques.

\subsection{Sample}

Determining the sample size is conditioned upon achieving a compromise between the need to have a large enough sample that could serve to obtain statistically significant results, and secondly, the need to obtain detailed information relevant to social performance which involves working on a relatively small sample. Faced such these constraints, we have decided to study business firms pertinent to the SBF 250 index. The selected companies are listed ones over the period 2007-2011. The choice of companies belonging to the SBF 250 index is justified by the fact that with respect to the Federation of Employee Shareholders and Former Employees (FAS), such firms undertake a highly developed employee ownership and shareholding strategy. Hence, this initial sample is likely to ensure a good representation in terms employee involvement and commitment level in the corporate governance system.

Table 1: Constitution of the final sample

\begin{tabular}{ll}
\hline Constitution of the final sample & 250 \\
\hline Initial sample before reprocessing (SBF 250 on December 31, 2011) & 36 \\
Companies belonging to the banking / insurance / investment / Real Estate sector & 106 \\
Companies whose annual reports and some information have been unavailable, incorrect or incomplete & 108 \\
Final sample & \\
\hline
\end{tabular}

Noteworthy, however, such firms as banks, insurance and investment companies, brokerage firms, portfolio management and development companies making part of the SBF 250 index have been excluded from the sample awing to the fact that these firms have an accounting structure that greatly differs from that of the of industrial and commercial companies, which does not allow for a homogeneous statistical processing. Moreover, companies whose annual reports and some information have not been available or complete have also been eliminated. Indeed, some data incompleteness has not been observed with regard to the applied information sources. Following, the entirety of the necessary treatments undertaken, the final sample turns out to consist of 108 companies. The 
following table depicts data figures relevant to the constitution of the sample.

The 108 companies constituting the sample are predominantly listed in the first market (82), as well as the second (23) and the new market (3). Once can also notice that more than half of the companies belong to the industrial sector and that $20 \%$ among them are part
Employee Shareholding Index (IAS). The 108 companies belong to different economic sectors, as determined on the basis of the NAF codes indicated in the database, relevant, to the company's main activity of the company. Actually, we have grouped the companies into ten sectors, as shown in Table 2 below.

Table 2: Sample companies repartition into activity sectors and stock market listing

\begin{tabular}{|c|c|c|c|c|c|}
\hline Activity sectors & Firms' number & $\begin{array}{l}\text { Firms' } \\
\text { percentage }\end{array}$ & Stock Market & $\begin{array}{l}\text { Companies' } \\
\text { number }\end{array}$ & $\begin{array}{l}\text { Companies' } \\
\text { percentage }\end{array}$ \\
\hline Processing Industry & 12 & $11,11 \%$ & \multirow{2}{*}{ First market } & \multirow{2}{*}{82} & \multirow{2}{*}{$75,92 \%$} \\
\hline Food Industry & 4 & $3,7 \%$ & & & \\
\hline Buildings and Public Works & 3 & $2,77 \%$ & \multirow[t]{2}{*}{ Second Market } & \multirow{2}{*}{23} & \multirow{2}{*}{$21,29 \%$} \\
\hline Trading and Distribution & 31 & $11,11 \%$ & & & \\
\hline Services & 9 & $28,70 \%$ & \multirow{6}{*}{ New Market } & \multirow{6}{*}{3} & \multirow{6}{*}{$2,77 \%$} \\
\hline Basic and Heavy Industry & 12 & $11,11 \%$ & & & \\
\hline High Tech & 22 & $20,37 \%$ & & & \\
\hline Communication & 5 & $4,6 \%$ & & & \\
\hline Chemistry & 3 & $2,77 \%$ & & & \\
\hline Energy & 7 & $6,48 \%$ & & & \\
\hline Total & 108 & $100 \%$ & & 108 & $100 \%$ \\
\hline
\end{tabular}

Business companies' structure in terms of size shows an overrepresentation of large firms employing more than 10,000 employees (Table 3).

Table 3: Sample distribution according to employee number

\begin{tabular}{lll}
\hline Number of employees & Number of Firms & Percentage of Firms \\
\hline More than 10,000 employees & 52 & $48,1 \%$ \\
Between 5,000 and 10,000 employees & 18 & $16,66 \%$ \\
Between 1,000 and 5,000 employees & 29 & $26,85 \%$ \\
Less than 1000 employees & 9 & $8,33 \%$ \\
Total & 108 & $100 \%$ \\
\hline
\end{tabular}

\subsection{Operationalization of Retained Variables}

The operationalization of variables, in particular that of the dependent variable, has sought to use indices initiated.

\subsubsection{The Explanatory Variable: Social Performance}

It is evidently clear that financial performance measures tend to be relatively more explicit than social-performance related ones. Noteworthy, however, data relevant to understanding social performance are most often obtained through surveys, characterized with the major drawback that the respondent's subjective interpretation can present. Hence, this entails restoring to the French companies published annual accounts including social statement which would help define comparable social variables relying on somewhat generally questionable bases. However, we encountered several difficulties in collecting information published by companies on social performance. One of these difficulties has to do with the nature of information, simultaneously quantitative and qualitative, static (measured at a given time) and dynamic (including Mchanges), such as staffing, training, health and safety, employee mobility, their compensation, satisfaction, social interaction, backgrounds diversity and working time. A second problem has been related to the wide array of information on human capital spread in several documents. In fact, in addition to the reference documents, such as annual accounts and management ones, most companies often publish a special report to sustainable development, with a section devoted to Human Resources. The amount of information available in these reports has made it necessary to undertake certain choices with respect to variables that can be applied to measure social performance. Actually, the retained variables have been selected on the basis of the following criteria: simple and little questionable data, data that best reflect the elements highlighted in previous empirical research (staffing, compensation, training ...) as well as the most frequently available data. Based on these criteria, it has been discovered that only three variables, or 
indicators, have proven to be available and fit for all firms subject of our sample.

The initially applied indicator pertains to compensation, social and payroll charges. This indicator is measured as follows: Part of the added value allocated to employees = wages + social charges + payroll charges + other incentives / added value. As part of a study dealing with humanresource management practices in the French family and non-family businesses, [80] attached a great importance to firms' willingness to retain or train staff as well as to remuneration policy and non-wage compensation. As for the second it indicator takes into account the training costs. Indeed, investment in training aimed at qualifying employees is likely to lead to increased human capital through knowledge constitution by means of learning ([17], [20], and [61]. In conformity with the study elaborated by [17] the ratio "training budget / payroll weight" has been used to assess the social performance intensity. Sustainable growth of social performance can only be achieved either by substituting personnel members by more qualified individuals, or by the continuous training of the labor force. The third applied indicator pertains to the companies adopted employment policy in, particularly, the evolution of the average number of employees (taking into account recruitment and job cuts). Indeed, the more growing the workforce evolution is, the firm saveguards the employees human capital (good employment relations'). This indicator is measured as follows: evolution in the number of employees $=$ number of employees $(\mathrm{N})$ - number of employees (N-1) / number of employees (N-1). To note, this ratio has been used in a study undertaken by [23] focusing on the relationship between innovation, employment and performance within French companies. Yet, this indicator has the disadvantage of being highly dependent on economic conditions. The latter, playing as the origin of job and recruitment cuts, it such conditions are differently interpreted from one company to another. So for the purpose of achieving dynamic indicators of social performance, we have reckoned it useful to examine these three indicators' evolution and trend over the entire study period, instead of merely applying their averages. In other words, we separately assign to each indicator a value (1) one an increase has been recorded, (0) otherwise. Hence, an increase would be recorded only, if the average variations in indicators over the next five periods (2006-2007, 20072008, 2008-2009, 2009-2010, 2010-2011) should be strictly greater than zero (the threshold is zero). A decline or stability is recorded in case the mean variations' changes in indicators over the next five periods (2006-2007, 2007 2008, 2008 -2009, 2009 - 2010, 2010 -2011) is inferior than or equal to zero. Thus, our variables to explain turn out to be dichotomous variables.

Table (4), below, depicts the correlation coefficients Kendall Tau-B among the three explanatory variables. As a matter of fact, correlation proves to be positive and significant among the three binary variables measuring social performance. In fact, reckon to reach relatively similar results by using, as dependent variable, the evolution in employees' number, the value added share denoted to employees or the training budget based on the payroll.

Table 4: Correlations between variable to explain (Social Performance)

\begin{tabular}{lllll}
\hline $\begin{array}{l}\text { Correlation } \\
\text { coefficients }\end{array}$ & Variables & $\begin{array}{l}\text { Evolution } \\
\text { in the } \\
\text { number of } \\
\text { employees }\end{array}$ & $\begin{array}{l}\text { Share of } \\
\text { value } \\
\text { added } \\
\text { allocated to } \\
\text { employees }\end{array}$ & $\begin{array}{l}\text { Training } \\
\text { budget } / \\
\text { payroll } \\
\text { weight }\end{array}$ \\
\hline & $\begin{array}{l}\text { Evolution in } \\
\text { the number } \\
\text { of } \\
\text { employees } \\
\text { Kendall }\end{array}$ & $\begin{array}{l}\text { Share of } \\
\text { value added } \\
\text { allocated to } \\
\text { employees } \\
\text { Training } \\
\text { budget } / \\
\text { payroll }\end{array}$ & $0,812^{* *}$ & $0.629 * *$ \\
\hline
\end{tabular}

** Significant at 1\% (bilateral), * significant at 5\% (bilateral)

\subsubsection{The Explanatory Variables}

The explanatory variables, as applied in this work, are twofold, namely: interest variables along with control ones. The interest variables studied in this research are three in number.

The employee's shareholding

The employee's shareholding variable to be measured in two ways. The first measurement procedure is a continuous variable pertinent to the capital percentage held by employees (ESOPS). The second procedure consists in retaining this variable as a dichotomous one. It takes the value (1), if the company has a significant employee ownership (at a $3 \%$ threshold), and (0), if the company has no employee-shareholders or should they be very low represented. In fact, since 1999, the Federation of Employee Shareholders and

Former Employees (FAS) has determined a significant employee-shareholding practice should the company have an employee stock holding of more than $3 \%$ of the capital.

The administrator employee variable

The first measure pertains to the percentage of employee directors in the board of directors or supervisory board (EMPDIR). As mentioned earlier, the second approach lies in retaining this variable as a dichotomous variable which takes the value (1) if the employee shareholders are represented on the board of directors or supervisory board and the value (0), if the company has no employee directors.

The CEO entrenchment variable

Most often, the operationalization of directors' entrenchment is performed using the following criteria: the share of capital held by directors', the duration in officer of a director ([7], the CEO age [66], the number of terms registered by the directors [81], anti-takeover defense strategy [62] and the directors turnover [15]. In the present research work, three entrenchment indicators have been 
applied "ENTRCH": the registered number of terms undertaken by the $\mathrm{CEO}$, the mean number of terms registered by directors in their entirely, and the CEO age. For testing purpose regarding the directors' entrenchment' variable, we exclusively use the second (TERMS) and the third measurement (AGE), as they have yielded more satisfactory results throughout the parameter estimation phase. With respect to the control variables, three among them have been on the basis of influence they can have on social performance. The first variable represents the financial performance level. Actually, this variable has been included in our study for the sake of recognizing whether social performance does depend on the performance of the financial undertaking or whether it rests on the interest considerations related to employees and other stakeholders, within a value creating or destroying perspective. Our choice coincides with Tobin's Q as a business performance measurement. With regard to our study, equity an approximation of Tobin's Q is retained, calculated as follows [21]: Tobin's $\mathrm{Q}=$ (equity market value + debt accounting value) / book assets.

As for the second control variable, it consists in the firm size, measured by the logarithm of the firm's total assets' booking value. The third control variable retained is debt. It constitutes a fundamental variable in regard of corporate finance relevant researches, particularly concerning value creation decision. As part of our analysis, a purely accounting measure is undertaken through the debt ratio (DEBT), calculated via the ratio: total financial debt / total assets [34]. For the sake of characterizing our sample (Table 5), some descriptive statistics elements are proposed, as depicted in table 5 .

For synthesis purposes, Table (6) depicts each model's variable measurement, their denomination along with their expected influence on the investment intensity pertinent to human capital and employment.

\subsubsection{Information Sources}

The used data pertain to four different sources, namely, the company annual report and the Internet, along with the Diane Dafsalien and Worldscope databases.

The annual report and the Internet

Prior setting up the database, all the companies' annual reports, subject of the final sample, have been downloaded, as they constitute our primary source of information. The annual report includes a section frequently addressing the human resource management function as well as the social balance. Data has been extracted from a pre-established database: SBF 250 and from the following sites: www.cob.fr;www.rapportannuel.com;www.edubourse.com; www.societe.com. At an ultimate stage, we used the Who's Who (Jacques Lafitte Editions), which contains biographical information and notices relevant a number of personalities in France. We have applied the Internet available version (www.whoswho.fr) for access to some leaders' biography pertaining to our sample. The information collected relates to director's birth date (CEO age) regarding the case in which it has not been available in the annual report.

Diane database: The Diane data base has offered us access to the following information: salaries, social charges, payroll taxes as well as to other forms of incentive and added value. Worldscope database: Data concerning the number of employees have been gathered from the Worldscope database. Dafasalien database: Data relevant to the percentage of capital held by employees, the percentage of state held capital, the percentage of employed directors and leaders' entrenchment have been collected from the DAFSALIEN database.

\subsubsection{The Estimation Method}

In this respect, the objective lies in showing the ways how the hypotheses $\mathrm{H} 1, \mathrm{H} 2$ and $\mathrm{H} 3$ have been tested. More specifically, it consists in explaining social performance bases on corporate governance variables. Three control variables (performance, size and debt) are also taken into account. The undertaken method rests on a multiple regression analysis, more specifically, on logistic regressions. Indeed, since the dependent variable explanatory is a dichotomous one, a logistic regression proves to be particularly fit to our approach in that it does not proceed in an additive, way, but, rather, in an interactive manner, unlike a discriminant analysis [31]. According to the explanatory variables' approach, three regressions or equations are estimated, namely:

Model 1 holds ESOPS (the share of employee-held capital) and EMPDIR (the percentage of employed directors) as continuous variables;

Model 2 retains both the ESOPSBI and EMPDIRBIN variables as binary ones;

Model 3 accounts for a variable that helps perceive the employees' weight within in governance bodies (WT). It is, actually, a binary variable that takes the value (1) should there be a simultaneous presence of employees both in the capital (whatever the firms' capital detention threshold might be firm) and in the directors' board or supervisory board, the value $(0)$ otherwise. In a next stage, models 1,2 and 3 are, then, reproduced by substituting the variable AGE by the TERMS one for the sake of checking the results' sensitivity to the director- entrenchment measures. Overall, a sum of 18 equations will be assessed. The models to estimate are presented as follows:

(EMP i, ADDEMP $i$, TRAIEMP $i,)=\beta 0+\beta 1$ ESOPS $i$ $+\beta 2$ EMPDIR $i+\beta 3$ ENTRA $i+\beta 4$ Q de Tobin $i+\beta 5$ Log (actif i) $+\beta 6$ DEBT $i+\varepsilon i \quad$ (MODELE 1)

(EMP i,, ADDEMP i,, TRAIEMP i,) $=\beta 0+$ $\beta 1$ ESIOPSBIN $i+\beta 2$ EMPDIRBIN $i+\beta 3$ ENTRA $i+\beta 4$ $\mathrm{Q}$ de Tobin $\mathrm{i}+\beta 5 \log (\operatorname{actif} \mathrm{i})+\beta 6$ DEBT $\mathrm{i}+\varepsilon \mathrm{i}$ (MODELE2)

$($ EMP $i$, ADDEMP $i$, TRAIEMP $i)=,\beta 0+\beta 1 \mathrm{WTi}+\beta 2$ ENTRAi $+\beta 3$ Q de Tobin $i+\beta 4 \log ($ actif $i)+\beta 5$ DEBT $i$ $+\varepsilon \mathrm{i}$ (MODELE3) 
Table 5: sample descriptive statistics

\begin{tabular}{|c|c|c|c|c|c|}
\hline Variables & Mean & Standard deviation & Median & Minimum & Maximum \\
\hline Evolution in the number of employees & $3,321 \%$ & $8,582 \%$ & $2,254 \%$ & $-27,158 \%$ & $24,369 \%$ \\
\hline Share of value added allocated to employees & $61,981 \%$ & $15,128 \%$ & $38,313 \%$ & $10,397 \%$ & $106,746 \%$ \\
\hline Training budget / payroll weight & $4,323 \%$ & $1,621 \%$ & $3,147 \%$ & $2,144 \%$ & $6,321 \%$ \\
\hline$\%$ of Employed Directors & $0,492 \%$ & $2,147 \%$ & 0 & 0 & $14,93 \%$ \\
\hline$\%$ of Employed Shareholders & 1,623 & 0,817 & 0 & 0 & 7,236 \\
\hline Average tenure of directors' terms & 8,314 & 4,247 & 7,012 & 1 & 26 \\
\hline CEO age & 52,634 & 7,342 & 53 & 42 & 69 \\
\hline Tobin's Q & 1,284 & 0,196 & 1,114 & 0,874 & 1,542 \\
\hline SIZE & 6,324 & 1,721 & 5,184 & 8,639 & 0,724 \\
\hline DEBT & 0,239 & 0,154 & 0,274 & 0,127 & 0,591 \\
\hline
\end{tabular}

Table 6: Summary of determinants to test and estimated relationships

\begin{tabular}{|c|c|c|c|c|}
\hline Endogenous variable & Indicators & Labels & & \\
\hline \multirow{3}{*}{ employment policy } & $\begin{array}{l}\text { Evolution of the number of hired employees = employee } \\
\text { number }(\mathrm{N}) \text { - Employee Number (N-1) / employee number } \\
(\mathrm{N}-1) \text {. }\end{array}$ & EMP & & \\
\hline & $\begin{array}{l}\text { Share of added value allocated to employees }=\text { wages }+ \text { social } \\
\text { charges }+ \text { payroll taxes }+ \text { other incentive } / \text { added value }\end{array}$ & ADDEMP & & \\
\hline & Training budget / payroll weight & TRAIEMP & & \\
\hline Exogenous variables & Indicators & Name & Sign & Hypothesis \\
\hline Employee & $\begin{array}{l}\text { - A continuous variable:\% of detained capital employee } \\
\text { (continuous variable) }\end{array}$ & ESOPS & & \\
\hline shareholding & $\begin{array}{l}\text { - A binary variable: } 1 \text { if significant presence in the capital does } \\
\text { exist ( } 3 \% \text { threshold), } 0 \text { otherwise. }\end{array}$ & ESOPSBIN & + & $\mathrm{H} 1$ \\
\hline Employee directors & $\begin{array}{l}\text {-A continuous variable: } \% \text { of employees in the Board of } \\
\text { Directors } \\
\text { - Binary variable: } 1 \text { in the case of presence in the board, } 0 \\
\text { otherwise. }\end{array}$ & $\begin{array}{l}\text { EMPDIR } \\
\text { EMPDIRBIN }\end{array}$ & + & $\mathrm{H} 2$ \\
\hline Weight of employees & $\begin{array}{l}\text { - A binary variable } \\
\text { Which takes the value (1) if there is a simultaneous presence } \\
\text { of employees in the capital, whatever the company capital } \\
\text { detention threshold might be, and the board of directors or } \\
\text { supervisory board and }(0) \text { value otherwise. }\end{array}$ & WT & + & $\mathrm{H} 1$ and $\mathrm{H} 2$ \\
\hline $\begin{array}{l}\text { Management } \\
\text { entrenchment } \\
\text { ENTR }\end{array}$ & $\begin{array}{l}\text {-Continuous variable: the average number of all directors' } \\
\text { cumulative terms. } \\
\text { - CEO age }\end{array}$ & $\begin{array}{l}\text { TERMS } \\
\text { AGE }\end{array}$ & + & H 3 \\
\hline Control variables & Indicators & Labels & & \\
\hline Size & Total assets log & SIZE & & \\
\hline $\begin{array}{l}\text { Financial } \\
\text { Performance }\end{array}$ & $\begin{array}{l}\text { Tobin's Q proxy = (equity market value }+ \text { debt book value }) / \\
\text { book assets }\end{array}$ & PERF & & \\
\hline Debt & Total Financial Debt / total assets & DEBT & & \\
\hline
\end{tabular}

\section{Results Achieved and Interpretations}

The regression results are synthetically depicted in tables $(7,8$, and 9) below. The models have been selected after several exhaustive iterations and following the removal some unnecessary irrelevant observations in a bid to present the best results of the model's general validity tests of be it for their prediction ability, their data adjustment quality, their explanatory power along with their overall significance (allowing to reject the null hypothesis stipulating that the coefficients are, in their entirely, equal to zero). It is worth noting, however, that on examining tables ( 7 and 8$)$ one might well drain a noticeable be conclusion. With the exception of equations (5 and 6), one can notice an overall persistence of a positive and significant influence of employee ownership (as a continuous and binary variable) on the probability of increasing social performance indicators. This finding puts in question view point of [67] stating that shareholding 
democracy is a wandering stray. Indeed, this author has postulated that the employee / shareholder is, thus, placed in a "delicate" situation as an employee, who wants driven by the desire to gain wage increases and permanent employment, but as a shareholder, he seeks maximum performance or turn over for his savings, usually implying to look for a reduction in labor costs incurred by the company. Still, this reached result perfectly corroborates our hypothesis $\mathrm{H} 1$ as well as the ideas advanced by [65], [75], [55], and [30].

Table 7: Regression results of model 1 (with both continuous variables ESOPs and EMPDIR)

\begin{tabular}{|c|c|c|c|c|c|c|c|c|c|c|c|c|c|}
\hline \multirow[b]{2}{*}{ Variables } & \multirow[b]{2}{*}{ Sign } & $\begin{array}{l}\text { ADDEMP } \\
\text { Equation } 1 \\
\end{array}$ & \multicolumn{3}{|c|}{ Equation 2} & \multicolumn{4}{|l|}{$\begin{array}{l}\text { TRAIEMP } \\
\text { Equation } 3\end{array}$} & \multicolumn{4}{|c|}{$\begin{array}{l}\text { EMP } \\
\text { Equation } 5 \quad \text { Equation } 6 \\
\end{array}$} \\
\hline & & ( $\beta)$ & Sign & $(\beta)$ & sign & $(\beta)$ & Sign & ( $\beta)$ & sign & ( $\beta)$ & sign & ( $\beta)$ & Sign \\
\hline Constant & &,- 508 & & ,202 & &,- 445 & &,- 850 & &,- 093 & &,- 968 & \\
\hline ESOPS & + & ,409 &, $017 * *$ & ,342 &, $077 *$ & ,366 &, $029 * *$ & ,345 &, $046 * *$ &, 188 & ,228 &, 141 & ,366 \\
\hline EMPDIR & + &,- 009 &, 547 &,- 001 & ,960 & ,011 & 919 & ,028 & ,788 &,- 165 & ,204 &,- 129 & ,308 \\
\hline AGE & + & ,139 &, $016 * *$ & ------ & -------- &, 077 &, 125 & -------- & -------- & ,093 &, $063 *$ & -------- & ------- \\
\hline TERMS & + & -------- & -------- & ,283 &, $000 * * *$ & -------- & ------ &, 120 &, $033 * *$ & -------- & ------ &, 176 &, $003 * * *$ \\
\hline PERF & $+/-$ & $-2,670$ &, $039 * *$ & $-3,297$ &, $022 * *$ & $-2,308$ &, $078 *$ & $-2,326$ &, $079 *$ & $-3,293$ &, $013 * *$ & $-3,492$ &, $012 * *$ \\
\hline SIZE & $+/-$ &,- 178 & ,475 &,- 552 &, $051^{*}$ &, 071 & ,769 & ,209 & ,399 &,- 162 &, 505 &,- 377 &, 143 \\
\hline DEBT & $+/-$ &, 036 &, 125 &, 020 & ,450 &, 012 & ,987 & ,011 & ,618 &, 006 & ,778 &, 011 &, 635 \\
\hline $\begin{array}{l}\text { Cox and Snell } \\
\text { R2 }\end{array}$ & ,314 & & & ,410 & & ,285 & & ,298 & & ,302 & & ,337 & \\
\hline X2 for & 40,765 & & & 57,023 & & 36,211 & & 38,177 & & 38,837 & & 44,374 & \\
\hline adjustment & $\mathrm{P}=0,0$ & $0 * * *$ & & $\mathrm{P}=0,000$ & & $\mathrm{P}=0,000 * * *$ & & $\mathrm{P}=0,00$ & & $\mathrm{P}=0,00$ & $* * *$ & $\mathrm{P}=0,00$ & \\
\hline $\begin{array}{l}-2 \text { Log } \\
\text { likelihood }\end{array}$ & 106,57 & & & 90,318 & & 112,581 & & 110,615 & & 110,289 & & 104,753 & \\
\hline
\end{tabular}

EMP, Evolution of the number of hired employees = employee number (N) - Employee Number (N-1) / employee number (N-1). ADDEMP, Share of added value allocated to employees $=$ wages + social charges + payroll taxes + other incentive / added value. TRAIEMP Training budget $/$ payroll weight. ESOPS, A continuous variable:\% of detained capital employee (continuous variable). EMPDIR, A continuous variable: \% of employees in the Board of Directors. TERMS, Continuous variable: the average number of all directors' cumulative terms. AGE, CEO age. SIZE, Total assets log. PERF, Tobin's Q proxy $=($ equity market value + debt book value $) /$ book assets. DEBT, Total Financial Debt $/$ total assets

$*, * *, * * *$, Respective significance at $10 \%, 5 \%$ and $1 \%$

The involvement of employee shareholders (comanagement) in the board of directors or supervisory board does not appear to have any statistically-significant effect on the probability of maintaining an effective social performance. This finding contradicts our assumption and the observation appearing in a report published by the French Institute of Corporate Governance [49] (IFGE, 2006) stating that: "It is logical to observe a correlation between the intensity in human capital investment and the presence of employee directors". This result is noticeable with respect to the entire set of indicators. Hence, it might be envisaged that the holding of a few seats by employees, in the board of directors or supervisory board does not constitute, by any means, a sufficient factor leading to a good social performance. In other words, the employee shareholder representatives on the board of directors or supervisory board do not enjoy enough power to protect employment and human capital of French firms' employees. This can also be explained by the low level of participation level of employed directors in French firms subject of our sample (with average of $0.492 \%$ ). Consequently, hypothesis (H2) turns out to be rejected.

According to Table (9), the WEIGHT variable proves to be significant. As result, the employees' simultaneous participation both in the capital and the directors or supervisory boards seems to highlight that the more the employees are present and involved in the decision-making and control bodies, the more important social performance turns out to be. Noteworthy, also, entrenched leaders tend to increase social performance. Indeed, the coefficients of the variables (AGE and MAND) are positive and significant in terms of evolution in employed staff number and the value added share allocated to them. Yet, it is positive but insignificant with regard to the association training budget / payroll (equations 3 and 9). This result appears to be consistent with the director's organizational entrenchment theory as developed by [43]. According to the latter, leaders engage in wage salary policies favorable to employees, with the aim of wining their alliance and favor in fighting shareholder in case of conflict. Indeed, to ensure the continuous perennity of their employment and strengthen further consolidate their roots and background, directors committed to safeguarding human capital and employment of salaried employees. This behavior may lead employees to support their directors in case of revocation decision taken by the directors' board. This highlights a partial confirmation of our hypothesis H3. 
Table 8: Regression results of model 2 (with binary variables ACTSAL and ADMSAL)

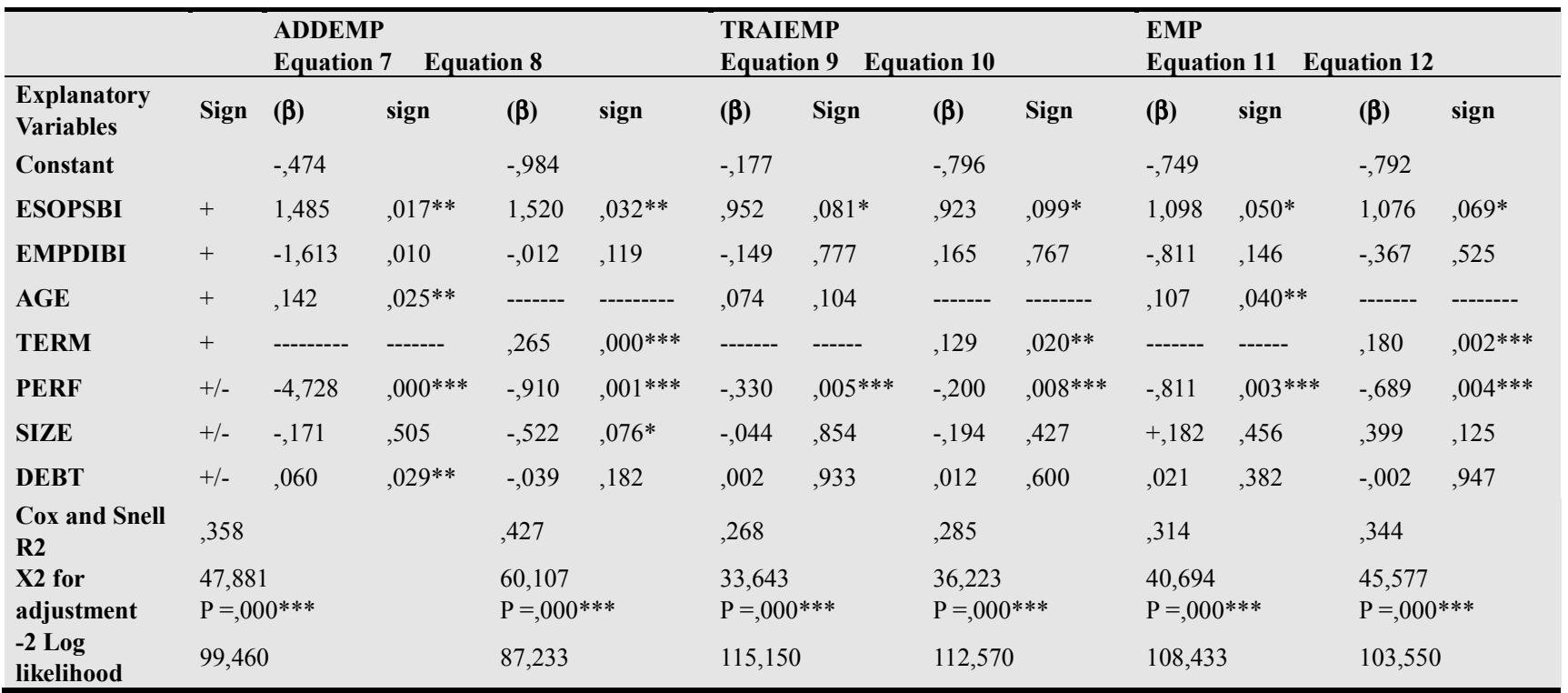

EMP, Evolution of the number of hired employees = employee number $(\mathrm{N})$ - Employee Number (N-1) / employee number (N-1). ADDEMP, Share of added value allocated to employees $=$ wages + social charges + payroll taxes + other incentive $/$ added value. TRAIEMP Training budget $/$ payroll weight. ESOPSBIN, A binary variable: 1 if significant presence in the capital does exist (3\% threshold), 0 otherwise. EMPDIRBIN, Binary variable: 1 in the case of presence in the board, 0 otherwise.. TERMS, Continuous variable: the average number of all directors' cumulative terms. AGE, CEO age. SIZE, Total assets log. PERF, Tobin's Q proxy $=$ (equity market value + debt book value) $/$ book assets. DEBT, Total Financial Debt $/$ total assets $*, * *, * *$, Respectively significant at $10 \%, 5 \%$ and $1 \%$

Table 9: Regression results of model 3: WT, Which takes the value (1) if there is a simultaneous presence of employees in the capital, whatever the company capital detention threshold might be, and the board of directors or supervisory board and (0) value otherwise

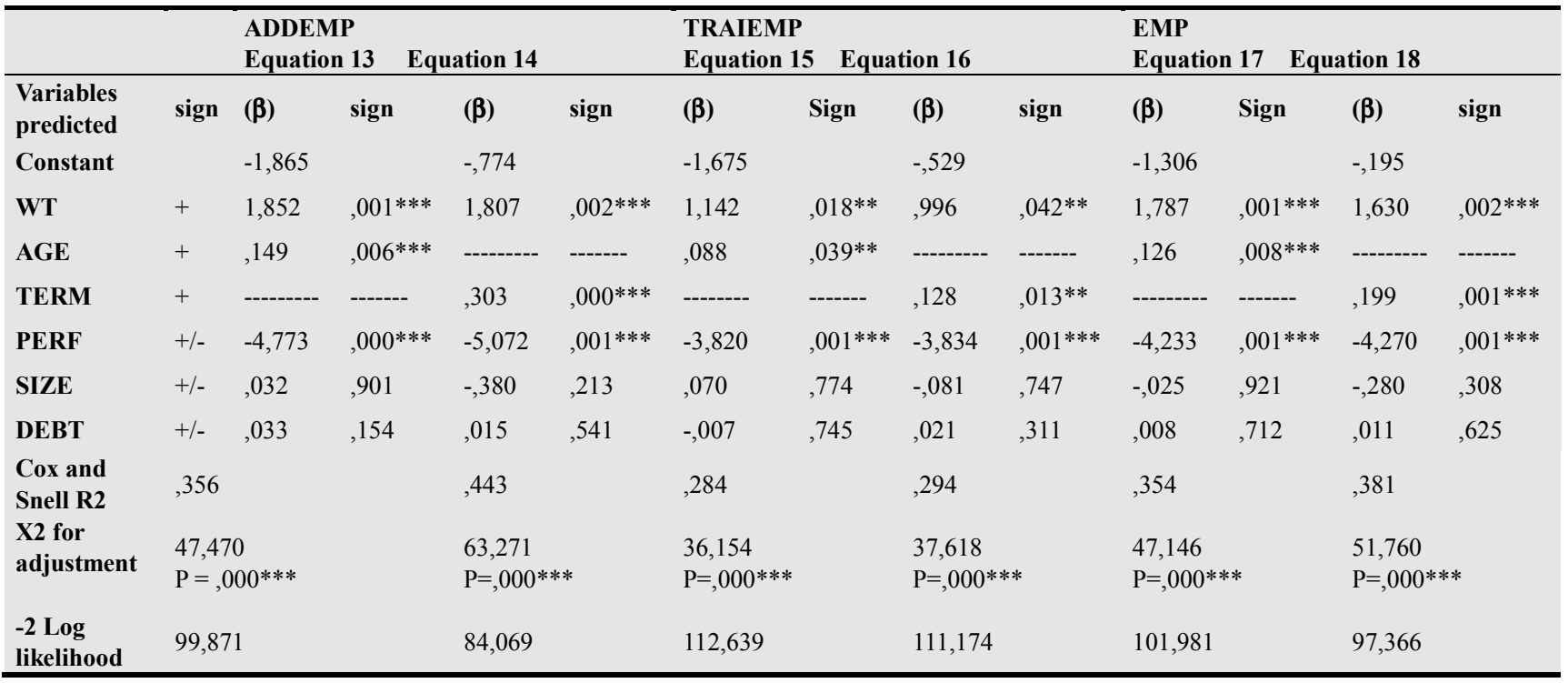

EMP, Evolution of the number of hired employees = employee number $(\mathrm{N})$ - Employee Number $(\mathrm{N}-1)$ / employee number $(\mathrm{N}-1)$. ADDEMP, Share of added value allocated to employees $=$ wages + social charges + payroll taxes + other incentive $/$ added value. TRAIEMP Training budget $/$ payroll weight. WT, Which takes the value (1) if there is a simultaneous presence of employees in the capital, whatever the company capital detention threshold might be, and the board of directors or supervisory board and ( 0 ) value otherwise. TERMS, Continuous variable: the average number of all directors' cumulative terms. AGE, CEO age. SIZE, Total assets log. PERF, Tobin's Q proxy = (equity market value + debt book value) / book assets. DEBT, Total Financial Debt / total assets

$*, * *, * * *$ Respectively significant at $10 \%, 5 \%$ an

The financial performance level negatively affects social performance. This influence is significant with respect to all equations. This finding may have its justifications in two different explanations. Firstly, successfully performing firms have greater concerns exceeding social objectives. Secondly, as stated by [9] salaried employees may be considered as the major, and often the inevitable, victims of financial performance. With regard to the French context, 
this finding is discovered inconsistent with elaborated by the study of The Swiss Confederation, conducted on a sample of 2143 private swiss companies. Indeed, The Swiss Confederation has reported that the more significant turnover decrease was during the years 1995-1997, the more staffing requirements (recruitment) declined, and, conversely, the higher the rise in turnover registered in this three years was, the more increased the needs for employee staff would.

In so far as, the size and debt are frequently cited variables with respect to most research works dealing with investment issues; it turns out to be worth noting that these variables proves to have mixed effects in respect of the equation to estimate.

On the basis these reached results, one might well state/confirm that employee ownership a shareholding and directors' entrenchment contribute, well among other factors, in explaining social performance.

\section{Conclusion}

Like any other research work, this paper has some limitations. The capital percentage held by employees does not match the percentage of voting rights. This information is available for U.S. firms. However, it is not available for French firms.

Another limitation is of technical type and does not allow us to give an absolute guarantee in terms of the produced results. In fact, certain means exist and are related to data collection, especially those related to employee participation in governance bodies and managers entrenchment and which were obtained "manually" from primary data. Under these conditions, the choice of the used regression model (logistic regression) can affect the quality and the signs of the found results.

However, these limitations should not reduce the scope of the original results which were obtained. One important result of the multi-varied analyses (logistic regression) is that on the whole employees, if they exert an influence on the determination of social performance in the context of non-financial French firms, are relatively powerless, on their own to explain this phenomenon.

Shares' holding by employees has a significant positive impact on social performance. The presence of French employees shareholders within the boards of directors or supervisory board has, in contrast, no statistically significant impact on job retention. However, the combined impact of employee participation in the capital and within the Board of Directors (the weight of employees) shows that the more employees are present in decision-making and control bodies, the more their human capital is protected. Our results confirm the idea that the work of employees and investment in human capital are a significant support for managers' entrenchment.

Although employee shareholding has often been used in previous studies to assess in particular the effectiveness of this control mechanism in the creation of value, the originality of our work is to have extended its impact on social performance while taking into consideration the active behavior of the manager. Our main position which bears on three domains which have not been studied simultaneously so far in the literature, namely employee shareholding, social performance and managers' entrenchment, testify that that these three areas can be closely connected.

\section{References}

[1] M Aglietta, (2000) «Shareholder value and corporate governance : some tricky questions » Economy and society

[2] R.C Andersen, T.W Bates, J.M Bizjak, \& M.L Lemmon, (2000), "Corporate governance and diversification", Financial management, vol. 29, pp. 5-22.

[3] M Aoki, (1984), « The co-perative game theory of the firm », Oxford university press.

[4] C.H Arcimoles (d'), (1999), «Les investisseurs face à la performance sociale de l'entreprise», Revue Française de Gestion, $\mathrm{n}^{\circ} 122$, janvier - février, pp 122-134.

[5] C.H Arcimoles (D'), \& S Trebucq, (2003), « Une approche du rôle de l'actionnariat salarié dans la performance et le risque des entreprises françaises», Revue de Gestion des Ressources Humaines, ${ }^{\circ} 48$, avril-mai-juin, pp. 2-15.

[6] J Armour, \& S Deakin, (2003), «Insolvency And Employement Protectin: The Mixed Effectts of The Acquired Righ Directive», International Review of Law And Economics, vol 23,pp 1-23;

[7] G Ballinger, \& J Marcel. (2010). "The use of an interim CEO during succession episodes and firm performance ». Strategic Management Journal vol 31, pp 262-283.

[8] L Batsch, (1995), «La régie d'entreprise: une approche comparative », Finéco, vol 5 n¹, pp 45-64.

[9] G Becker, (1962), " Investment in human capital: A theoretical analysis », Journal of Political Economy, vol. 70, no 5, 2e partie, p. 9 à 49.

[10] P Berger, E Ofek, \& D Yermack, (1997), « Managerial entrenchment and capital structure decisions », The Journal of Finance, vol 52, n4, September, pp1411-1438.

[11] M Blair, (1995), «Ownership and control: restringing corporate governance for the twenty first century, the Brookings institution», Washington. Brookings institutions.

[12] M Blair, (1999), «Firm-specific human capital and the theory of the firm», the Brookings institution», Washington. Brookings institutions.

[13] M Blair, \& T Kochan, (2000), The New Relationship : Human Capital in the American Corporation, Brookings Institution Press,

[14] J Blasi, M Conte, \& D Kruse, (1996), «Employee Stock Ownership and Corporate Performance among Public Companies ", Industrial and Labor Relations Review, Vol. 50 , Issue 1.

[15] R Bushman, Z Dai,., X Wang,., (2010). "Risk and CEO 
turnover". Journal of Financial Economics vol 96, pp 381398.

[16] R.P Castanias, \& C.E Helfat, (1992), «Managerial and windfall rents in the market for corporate control», Journal of Economic Behavior and Organization, vol 18, pp 153$184 .$.

[17] J Charest, (1999), " Articulation professionnelle et orientations du système de formation professionnelle au Québec ». Industrial Relations, vol. 54-3, pp 439-469.

[18] G CHARREAUX, (1997), «Le Gouvernement des Entreprises : Corporate Governance, Théories et Faits», Edition Economica, Paris, 540 p.

[19] G Charreaux, \& P Desbrieres, (1998), «Gouvernance des entreprises : valeur partenariale contre valeur actionnariale », Finance Contrôle Stratégie, vol 1, n², pp 57-88.

[20] Y Chassard, \& O Passet, (2005), « Faut-il craindre une pénurie de main-d'oeuvre qualifiée », Sociétal n ${ }^{\circ} 49$, pp 3641.

[21] K.H Chung, \& S.W Pruitt, (1994), « A Simple Approximation of Tobin's Q», Financial Management, vol $23 \mathrm{n}^{\circ} 3$, pp 70-74.

[22] B Cornell, \& A Shapiro, (1987), « Corporate Stakeholders and Corporate Finance », Financial Management, Spring, pp. 5-14.

[23] B Crepon, \& N Iuing, (1999), «Innovation, emploi et performances » Institut national de la statistique et des études économiques, Série des documents de travail, mars 1999, G 9904

[24] H Cronqvist., F Heyman., M Nilson., H Svaleryd., \& J Vlachos., (2009), "Do Entrenched Managers Pay Their Workers More ?”, Journal of Finance, vol. 64, n²1, pp 309339.

[25] S Hobbs Deakin, , R Konzelmann, And F Wilkinson, (2002), " Partnership, ownership and control: The impact of corporate governance on employment relations», Employee Relations; Vol 24 No. 3.

[26] C Decock Good, \& L Georges, (2003), «Gestion Des Ressources Humaines et Performance Economique: Une Etude Du Bilan Social », Comptabilité Contrôle Audit Tome 9 vol 2 pp 151-170.

[27] D.J Denis, D.K Denis, \& A Sarin, (1997), « Agency Problems, Equity Ownership, and Corporate Diversification», Journal of Finance, Vol 52(1), March, pp.135-160.

[28] P Desbrieres, (2002), «Les actionnaires salariés», Revue Française de Gestion, n¹41, nov - dec, pp 255-281.

[29] J Dondi, (1992), «Contribution à la connaissance de l'actionnariat des salariés», Thèse de Doctorat en Sciences de Gestion, Université de Bordeaux I.

[30] C Estay, (2000), «Intéressement et attitudes des salaries de l'entreprises, » Revue de Gestion des Ressources Humaines, $\mathrm{n}^{\circ} 35, \mathrm{pp} 20-40$.

[31] Y Evrard, B Pras, Et E Roux, (1993), « Market : Etudes et recherches en marketing: Fondements et méthodes», Dunod.

[32] F Fakhfakh, (2004), « The effects of profit sharing and employee share ownership on quits: evidence from a Panel of French Firms». Advances in the Economics of Participatory and Labor-Managed Firms, n ${ }^{\circ}$ : pp129-48.

[33] O Faleye, , V Mehrotra \& , R Morck (2006), « When Labor Has a Voice in Corporate Governance» Journal of Financial and Quantitative Analysis, vol.41, $\mathrm{n}^{\circ} 3$, pp 489-510.

[34] E.F Fama, \& K.R French, (2002), « Testing trade-off and pecking order predictions about dividends and debt ", Review of Financial Studies vol 15. pp 1-33.

[35] J Franks, \& C Mayer, (1992), «Corporate control: a synthesis of the international evidence», Working paper, London Business School et City University Business School, November.

[36] E.G Furubotn, (1988), «Codetermination and the modern theory of the firm: a property- rights analysis», Journal of The Business, vol 61, n², pp165-181.

[37] J.E Gamble, (2000), «Management Commitment to Innovation and ESOP Stock Concentration », Journal of Business Venturing, vol.15, pp 433-447.

[38] J.E Gamble, R Culpepper, \& Blubauch, M (2002), «ESOPs and Employee Attitudes: The Importance of Empowerment and Financial Value, ", Personnel Review Vol.31, No.1, pp. $9-26$

[39] R Garfatta. (2010) « Actionnariat Salarié et création de valeur dans le cadre d'une convergence actionnariale et partenariale : Application au contexte français » Université de Dijon

[40] G.T Garvey, \& P.L Swan, (1995), « Shareholder activism, « voluntary » restructuring, and internal labour markets ", Journal of Economics \& Management Strategy, vol. 4, $\mathrm{n}^{\circ} 4$, pp591-621.

[41] H Gharbi, (2006), " Actionnariat salarié : un tremplin à l'enracinement managérial», Congrès AFFI association française de finance, Bordeaux.

[42] H Gharbi, \& X Leprs, (2007), «actionnariat salarié et enracinement des dirigeants: vers une compréhension fondée sur la théorie du pouvoir et de la dépendance »15 éme Conférence Internationale de Management Stratégique (AIMS), Montréal.

[43] P.Y Gomez, (1996), « Le Gouvernement de l'entreprise : Modèles économiques de l'entreprise et pratiques de gestion», InterEditions.

[44] R Goodijik, (2000), «Corporate governance and workers' participation » Corporate governance, vol $8 \mathrm{n}^{\circ} 4$, pp 303310.

[45] L Gordon, \& J Pound, (1990)," ESOPs and Corporate Control", Journal of Financial Economics, vol. 27, pp 525555 .

[46] Z Guedri. \& X Hollandts., (2008), "Beyond Dichotomy: The Curvilinear Impact of Employee Ownership on Firm Economic Performance", Corporate Governance: an International Review, vol.16, n5, pp 460-474.

[47] C.W Hill, \& T.M Jones, (1992), « Stakeholder-agency theory », Journal of Management Studies, vol.29, n², Mars, pp 131-154.

[48] J Hubler, \& G Schmidt, (1996), « L'effet des annonces de 
décisions de G.R.H sur les cours boursiers des entreprises françaises. Application d'une méthodologie d'études d'événements», Actes des XIIIe journées nationales des IAE, Toulouse, Tome 1, p. 448-467.

[49] IFGE (Institut Français du Gouvernement d'Entreprise, 2000): «Les administrateurs salariés un atout pour la gouvernance des entreprises françaises ", http://www.ifgeonline.org.

[50] D.C Jones, P Kalmi,. \& M Makinen,. (2010) The productivity effects of stock option schemes: evidence from Finnish panel data. Journal of Productivity Analysis. 33: pp $67-80$

[51] S N Kaplan,. \& B A Minton, (2012).” How Has CEO Turnover Changed? "International Review of Finance, Vol. 12 , Issue 1, pp. 57-87.

[52] E.H Kim,. (2009)," Corporate Governance and Labor Relations". Journal of Applied Corporate Finance. Vol 21, Issue 1, pp 57-66,

[53] K Koike, (1990), "Intellectual skill and the role of employees as constituent members of larges firms in contemporary Japan ", Edited by Aoki et al. SAGE publications.

[54] B.Kramer, (2010) "Employee ownership and participation effects on outcomes in firms majority employee-owned through employee stock ownership plans in the US". Economic and Industrial Democracy. vol 31: pp 449-476.

[55] D Kruse, \& J Blasi, (1997)," Employee ownership, employee attitudes, and firm performance: A review of the evidence", in Mitchell D. J. B., Lewin D. et Zaidi M. (eds), Handbook of Human Resource Management, Greenwich, JAI Press, pp. 113-151.

[56] B Kuvaas, (2002)," Employee Ownership and effective Organizational Commitment: Employees' Perceptions of Fairness and their Preference for Company Shares over Cash", Scandinavian Journal of Management, Article In Press, Uncorrected Proof, Available online 6 January.

[57] R.S Marens, A.C Wicks, \& V.L Huber, (1999), «Cooperating with the disempowered, using ESOPs to forge a stakeholder relationship employee trust in workplace participation programs», Business and Society, vol.38, ${ }^{\circ} 1$, march, pp.5182.

[58] H.M Markowitz,. J.R Blasi,. \& D.L Kruse,. (2010) Employee stock ownership and diversification. Annals of Operations Research. 176: pp95 - 107

[59] A.C Martinet, \& E Reynaud, (2001), «Shareholders, stakeholders et stratégie ", Revue Française de Gestion, novembre-décembre.

[60] R Meng, X Ning, X \& Zhou H (2011),'Journal of Banking \& Finance, » 2011, vol. 35, issue 6, pp 1541-1551.

[61] E Nauze-Fichet, Et M Tomasini, (2002), « Diplôme et insertion sur le marché du travail : approches socioprofessionnelle et salariale du déclassement ", Economie et statistique, $\mathrm{N}^{\circ} 354$. pp 21-48.

[62] M Paquerot (1996), «Stratégies d'enracinement des dirigeants et prises de contrôle ", Thèse de Doctorat en Sciences de Gestion, Université de Bourgogne, janvier.
[63] S PARK, \& M SONG, (1995), "Employee Stock Ownership Plans, Firm Performance, and Monitoring by outside Blockholders", Financial Management, vol. 24,n²4, pp 52 65 .

[64] A Pendleton, N Wilson, \& M Wright, (1998), «The Perception and Effects of Share Ownership: Empirical Evidence from Employee Buy-Outs», British Journal of Industrial Relations, Vol. 36 Issue 1, pp.99- 123.

[65] A Pendleton,. (2010)," Employee share ownership and investment concentration: which employee shareholders fail to diversify?" Human Resource Management Journal. 20: pp $157-174$

[66] B Pige, (1998), « Enracinement des dirigeants et richesse des actionnaires », Finance Contrôle Stratégie, Vol.1, n³, septembre, p.131-158.

[67] D Plihon, (2002), «Rentabilité et risque dans le nouveau régime de croissance », Rapport du groupe de travail présidé par D. Plihon, CGP, octobre.

[68] T POULAIN-REHM, (2002), "Gouvernance d'entreprise et actionnariat des salariés : une approche conceptuelle», Revue du Financier, complément au $\mathrm{n}^{\circ} 133$ sur la gouvernance d'entreprise.

[69] T Poulain-Rehm, (2007), «L'actionnariat des salariés en France, un facteur de création de valeur ? " Banque \& Marchés Nº8, pp 25-36.

[70] W Pugh, J Jahera, \& S Oswald, (1999), «ESOPs, Takeover Protection, and Corporate Decision-Making », Journal of Economics and Finance, vol.23, n², pp170-185.

[71] W.N Pugh,. S.L Oswald,. \& J.S Jahera,. (2000), «The Effects of ESOP Adoptions on Corporate Performance: Are there Really Performance Changes? "), Managerial and Decision Economics, 21, pp. 167-180.

[72] R Rajan, \& L Zingales, (1998), « Power in the theory of the firm », Quarterly journal of Econonic, May pp 387-432.

[73] A Remond, (2002) «Quelle représentation pour les salariésactionnaires ? » Revue de l'IRES n ${ }^{\circ} 40$ - vol3.

[74] J Robert, \& E Van Den Steen, (2000), « Shareholder interests, human capital investment and corporate governance ", Working paper Stanford graduate school of business. 30 avril.

[75] A M Robinson, \& , H Zhang (2005), «Employee Share Ownership: Safeguarding Investments in Human Capital», British Journal of Industrial Relations, Vol. 43, No. 3, September, pp. 469-488.

[76] A Shleifer, \& R.W Vishny, (1989), « Management Entrenchment: the Case of Manager Specific investments ", Journal of Financial Economics, vol $25 \mathrm{n}^{\circ} 1 \mathrm{pp}$ 123-139.

[77] S. T Simon (2011),"Employee Stock Ownership: Effect on Strategic Management and Performance" PhD thesis, The $\mathrm{PhD}$ School of Economics and Management, Copenhagen business school;

[78] D.J Skinner, (1993), « The investment opportunity set and accounting procedure choice », Journal of Accounting and Economics, vol 16, $\mathrm{n}^{\circ} 1-2-3$, pp 407-445.

[79] C.S Smith, (1991), «On the economic rationale for codermination law», Journal of Economic Behaviour and 
Organization, vol 16, pp 261-281.

[80] M Spence \& S Hlatshwayo (2001), The Evolving Structure of the American Economy and the Employment Challenge, March 2011 working paper.

[81] L Taylor, (2010),' Why are CEOs rarely ...red? Evidence from structural estimation, 'Journal of Finance' vol 65, pp 2051-2087

[82] S Trebucq, (2002), « L'actionnariat salarié dans les entreprises familiales du SBF 250: un outil de création de valeur? », Finance Contrôle Stratégie, Vol 5, N4 ;

[83] S Trebucq \& C-H D'arcimoles, (2002), "The effects of ESOPs on performance and risk : Evidence from France",
11 éme Conference of the International Association for the Economics of Participation, Catholic University of Brussels, Bruxelles, 4-6 juillet.

[84] O.E Williamson, (1985), «The economic Institutions of Capitalism: Firms, Markets, and relational Contracting», New York, MacMillan Free Press.

[85] P Wirtz, (2000), « Gouvernement d'entreprise et politique de financement en France et en Allemagne», Thèse de doctorat. Université de bourgogne.

[86] J Zabonjnik, (1998), "Sales maximization and specific human capital », Rand Journal of Economics, vol $29 \mathrm{n}^{\circ} 4$, pp77-83. 